\title{
Ondernemingsrasionalisasie: Vernuwer of vernietiger van u werkerskorps
}

\author{
P. Claassen \\ Posbus 1091, Johannesburg, 2000 Republiek van Suid-Afrika \\ W. Backer* \\ Departement Bedryfsielkunde, Randse Afrikaanse Universiteit, Posbus 524, Johannesburg, 2000 Republiek van Suid-Afrika
}

Aanvaar 20 Maart 1989

\begin{abstract}
The rationalization of companies: Renewer or destroyer of the work-force. The rationalization of companies in the Western world has become almost an integrated part of modern management strategies. The downsizing syndrome has proven to be the favourite choice of many. Change, so many studies have proven, enhances resistance among employees. Change as experienced during the downsizing process, where retrenchment forms an inherent part of the strategy creates its own range of fears and expectations amongst employees. This study analyses the experiences of employees during the phases of destructive change. The hypothesis the study tested was that significantly more employees will rate the experience as extremely negative and that the main issue at stake is job security. It was found that although a significant proportion of the employees thought that dratic change was neccessary, they were bitterly unhappy with the way management introduced the change. It was also found that at the centre of unhappiness, threats to job security caused the most damage. Furthermore, it was proven that during change, a well-planned, pre-programmed exercise, with a definite beginning and end time creates significantly lesser stress and fear amongst employees than during a unstructured almost open ended process.
\end{abstract}

\begin{abstract}
Die rasionalisering van ondernemings in die Westerse wêreld het amper 'n geïntegreerde deel van moderne bestuurstrategie geword. Die verskralingsindroom, so blyk dit, is die gewildste keuse onder bestuur. Dit is deur baie studies bewys, dat verandering een of ander vorm van weerstand onder werknemers kweek. Verandering, soos dit deurleef word tydens verskraling en waar personeelvermindering inherent aan die proses is, skep sy eie unieke reeks vrese en verwagtings onder werknemers. Hierdie studie analiseer die ondervindinge van werknemers tydens fases van destruktiewe verandering. Die hipotese wat getoets is, is dat beduidend meer werknemers die proses as uiters negatief sal ervaar en dat die grootste faktor wat negatiwiteit beïnvloed werksekuriteitbedreiging sal wees. Daar is bevind dat alhoewel 'n beduidende aantal van die werknemers aangedui het dat verandering in hul organisasies noodsaaklik was, was hulle terselfdertyd bitter ongelukkig oor die wyse waarop verandering in die organisasie toegepas is. Daar is ook bevind dat die hoofoorsaak vir ongelukkigheid werksekuriteitbedreiging was. Vervolgens is daar statisties beduidende bewys dat goedbeplande, goedgestruktureerde veranderingspogings met ' $n$ duidelike begin en 'n einde baie minder stress en ongelukkigheid veroorsaak as pogings wat onbeplan, ad hoc en amper tydloos van aard is.
\end{abstract}

\section{Inleiding}

"We trained hard, but it seemed that every time we were beginning to form up into teams we would be reorganised. I was to learn later in life that we tend to meet any new situation by reorganising, and a wonderful method it can be for creating the illusion of progress, while producing confusion, inefficiency and demoralisation' - Caius Petronius AD69.

Ondernemingsrasionalisasie het 'n modegier geword. Ondernemings wat skynbaar die pyne van oneffektiwiteit voel, of in 'n selfgeskepte milieu van ondergang leef, loods graag hierdie tegniek om hul ondernemings op die vernuwingspad te plaas. Petronius hierbo noem dit die illusie van vooruitgang. Wat is hierdie proses by name van ondernemingsrasionalisasie en hoe beleef werknemers hierdie drastiese ingryping van bestuur? Die skrywers het oor 'n bestek van drie jaar 'n diepgaande studie oor die mannekragbestuurskomponent van ondernemingsrasionalisasie geloods, en die resultate hiervan word hieronder bespreek.

\section{Ondernemingsrasionalisasie: 'n Definisie}

Ondernemingsrasionalisasie is daardie proses waardeur 'n onderneming poog om vir enige kombinasie van redes sy hulpbronne en/of prosesse so te herstruktureer, dat die doelwit wat voortspruit uit die redes vir die stap, geoptimaliseer word. Die doelwit kan verskraling of vergroting van aktiwiteite wees, maar het as einddoel 'n resultaat wat die persepsie laat dat die proses suksesvolle vernuwing meegebring het. Dit is ' $n$ intervensie van verandering met vernuwing of oorlewing as einddoel.

Die rasionalisasieproses kan van gedeeltelike of totale aard wees. Tydens laasgenoemde proses bestaan die geneigdheid by bestuur om alle prosesse en sisteme te vernuwe. 'n Rasionalisasiekoors, wat 'n begeesterde dryfkrag vir vernuwing as voedingsbron het, is dan tiperend van bestuurders se gedrag. Rasionalisasie is uiters kompleks in totale formaat. Dit spreek alle bedryfsprosesse gelyktydig aan .... vir die mannekragbestuurder kan dit 'n klimaks in beroepservaring wees. Hierdie artikel fokus primêr op die werknemerservarings tydens so 'n proses.

\section{Probleemstelling}

Geen omvattende studie oor die ervarings van werknemers tydens ondernemingsrasionalisasie kon deur die skrywers opgespoor word nie. Rasionalisasie het ' $n$ modegier geword en tog, soos vermoed deur die skrywers, word bitter min aandag geskenk aan die verwagtinge en vrese van werknemers tydens die proses. Enersyds omdat bestuur nie die uitkoms van werknemers as 'n primêre oorweging nodig ag nie en 
andersyds omdat hulle nie weet hoe werknemers gaan of kan reageer nie en dus nie in hul detailbeplanning daarvoor voorsiening maak nie. Die studie is onderneem om die teorie van rasionalisasie vanuit 'n mannekragbestuursperspektief te formuleer en in aansluiting daarby is metings in die praktyk onderneem om vas te stel hoe werknemers die prosesse van destruktiewe verandering deurleef.

\section{Navorsingsmetodiek}

Ten einde vas te stel hoe werknemers rasionalisasie beleef ten opsigte van hul tevredenheid en ontevredenheid met die proses is 'n vraelys aan 350 toesighouers en middelbestuurders in verskeie ondernemings gegee vir voltooiing. Die vraelys het ruimte gehad vir 'n blote 'Ja' of 'Nee' antwoord, asook 'n ruimte vir verduideliking waarom die respondent tevrede of ontevrede gestem is. Die vraelys het die volgende aspekte gedek:

- of werknemers bestuur se gevoel deel oor nodigheid vir rasionalisasie;

- bestuur se hantering van die saak aldus hulle persepsie;

- produktiwiteit tydens die proses;

- kommunikasie tydens die proses;

- organisasiestrukturering;

- aanvaarbaarheid ten opsigte van die tydsduur van die proses;

- persoonlike ervarings ten opsigte van onsekerheid, konsultasie en meelewing, gesinsongerief, ens.;

- personeelvermindering en die impak daarvan;

- gesondheidsgevolge;

- vakunielidmaatskapoorweging;

- arbeidsomset; en

- algemene indrukke.

Die skrywers se bevindinge is dat rasionalisasie deur ' $n$ statisties beduidende persentasie werknemers as uiters traumaties beleef word. Meer as $70 \%$ van die respondente was, alhoewel hulle met bestuur saamgestem het oor die nodigheid van rasionalisasie, oor 'n wye reeks van dimensies ontevrede met dit wat hulle deurleef het. 'n Radarmodel wat die mate van ontevredenheid teenoor tevredenheid ten opsigte van die ondergenoemde faktore uitbeeld, is uit die resultate saamgestel.

\section{Radarmodel oor 22 dimensies ten opsigte van personeel se ervarings van die proses}

Die model word vanuit die negatiewe en positiewe verband aangebied, met ander woorde elke as se waarde verteenwoordig die kumulatiewe negatiewe of positiewe response wat verkry is vir die betrokke vraag of groeperings van vrae, waar van toepassing. Die aswaarde is deurgaans 100 en is uitgedruk as 'n persentasie (\%).

Die syfer in hakies verteenwoordig die nommer of beskrywing van die as volgens die indeks. Die dimensies hierin uitgebeeld is soos volg:

1. die nodigheid vir rasionalisasie al dan nie;

2. is die personeel gekonsulteer;
3. is die metodiek wat toegepas is, goed;

4. was bestuur se hantering goed;

5 . word lojaliteit en vertroue behou;

6. was kommunikasie met personeel goed;

7. was beplanning goed;

8. was kommunikasie geloofwaardig;

9. was gerugte volop;

10. was organisasiestrukturering goed;

11. was die tydsverloop aanvaarbaar;

12. het produktiwiteit van werkers gedaal;

13. was bestuur sensitief vir produktiwiteit;

14. was werknemers baie onseker;

15. sal werkers finansieel skade ly;

16. was werknemers bang vir werkverlies;

17. glo werknemers mense gaan afgedank word;

18. het personeelvermindering 'n negatiewe of positiewe beeld gelaat;

19. het werknemers bedanking oorweeg;

20. het werknemers dit oorweeg om by 'n vakunie aan te sluit;

21. was werknemers onbillik behandel;

22. is werknemers se gesondheid beïnvloed.

Die 'Ja' en 'Nee' antwoorde is statisties getoets vir beduidende verskille tussen die positiev'e en negatiewe ervarings deur die respondente. Die Chi-kwadraattoets soos beskryf deur Malik \& Mullen (1975: 299) is gebruik. Die volgende resultaat het gerealiseer: 25 antwoorde het statisties beduidend gediskrimineer by $X^{2}{ }_{0.95}$ met $K=1$ en tabelwaarde $=\mathbf{3}, 8416$.

Slegs in vier gevalle is onbeduidende verskille

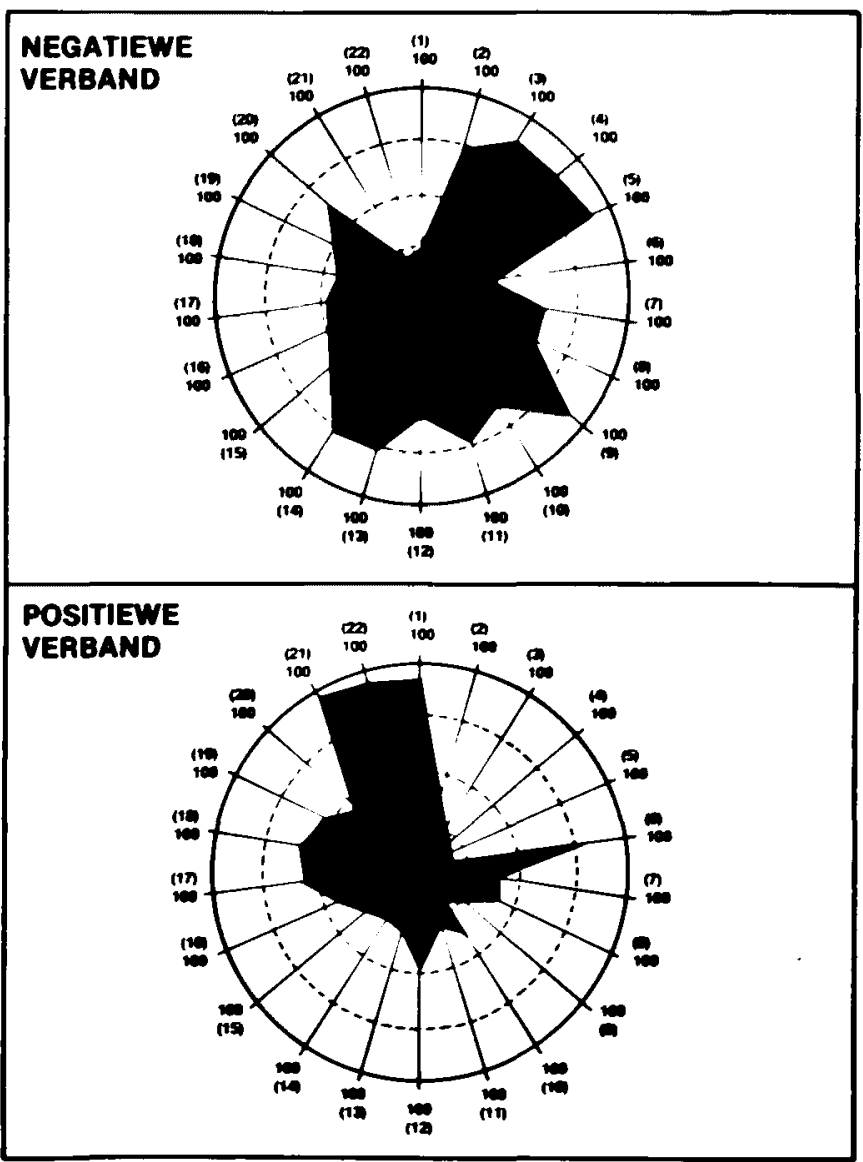

Figur 1 Radarprofiel: Ontevredenheid teenoor tevredenheid 
aangeteken. Die rigting van verskil was hoofsaaklik negatief met slegs vier vrae wat na die positiewe kant diskrimineer. Die vier positiewe antwoorde is ten opsigte van oorweging van vakunielidmaatskap, gesondheidsgevolge, onbillikheid en die nodigheid vir rasionalisasie al dan nie, aangeteken. Statisties gesproke kan daar dus aanvaar word dat werknemers rasionalisasie oorwegend negatief beleef.

\section{Kemgevolgtrekkings uit die eerste fase van die studie}

Dit blyk asof die simptome wat rasionalisasie vooruitloop deur werknemers waargeneem word. Waarskynlik is hulle waarnemings voortvloeisels van die klimaat wat op daardie stadium in die organisasie heers. Werknemers vertolk egter die simptome anders as bestuur en heg hul eie unieke redes aan die noodsaaklikheid vir die stap. Die skrywers se waarneming is dat daar twee uiteenlopende wêrelde van gedagtes ontstaan - 'n bestuursperspektief en 'n werknemerperspektief. Reeds voor die aankondiging van rasionalisasie is daar dus inherente konflik in die proses opgesluit. Bestuur kan moontlik ander stappe doen as dit wat geredelik deur werknemers verwag word.

Werknemers distansieer hulle van die proses omdat hulle die gevoel beleef dat hulle belange sekondêr is in die nuwe bestel. Hulle word nie inspraak gegun nie en ervaar dus nie eienaarskap nie. Vervolgens ontstaan die indruk by hulle dat die organisasie 'n rigting forseer al kos dit ook die loopbane van menige werknemers.

Die skrywers se bevinding rondom kommunikasiebehoeftes by werknemers tydens en net voor rasionalisasie is dat primêre kommunikasiebehoeftes sentreer rondom die uitkoms van die individu in die nuwe bestel. Die werknemer wil weet waar hy staan. 'n Algehele sekondêre belang oor hoe die onderneming gaan uitsien na rasionalisasie is aanwesig. Inteendeel, die skrywers se afleiding is dat onsekerheid oor die individu se eie bestel 'n baie sterk filter is wat sy vermoë om aandag te skenk aan nuwe eise van die 'nuutgemaakte' organisasie, heeltemal aantas. Hy of sy hoor nie die boodskap voordat werksekerheid verseker is nie. Gerugverspreiding oorheers die kommunikasieterrein en die informele kommunikasiekanaal word 'n baie kragtige medium wat selfs die formele kommunikasiepoging oorheers. 'n Halfmas kommunikasiepoging deur bestuur word reeds vroeg heeltemal verswelg deur gerugte. Die gerugte, so blyk dit, fokus primêr rondom werkverlies, personeelverminderingspraatjies en personeelontwrigting. Weens die baie verandering in planne om onvoorsiene omstandighede, vind werknemers kommunikasie ongeloofwaardig. Bestuur hou, aldus hulle, nie by hulle beloftes nie. Vertrouensbreuk is dus die kwessie.

Produktiwiteit, aldus die persepsie van die oorgrote meerderheid werknemers, daal baie skerp tydens rasionalisasie. Dit word toegeskryf aan hulle vrees vir werkverlies, ontwrigting weens massa herontplooiings en vele ander rasionalisasieaksies. Daar is ' $n$ beduidende tendens wat daarop dui dat produktiwiteit weer grootliks herstel sodra werksekuriteit herstel is. Hoe langer die fase tussen die rasionalisasie-afkondiging en die 'heraanstelling' van die individu, hoe laer daal sy produktiwiteit. Hayes \& Nutman (1981) beweer dat onder sulke omstandighede tot $75 \%$ van die werknemer se psigiese energie aangewend word om onsekerheid te beveg. Hy kanaliseer dus sy vermoë eerder na oorlewing as na produksie tydens fases van werkverliesvrees. Rasionalisasie is by uitstek 'n poging wat sulke omstandighede kweek.

Die meerderheid werknemers is oortuig dat hulle lojaliteit jeens, en hulle vertroue in die onderneming geweldig daal tydens rasionalisasie. Die skrywers se opinies is dat dit veroorsaak word deur die geweldige mate van loopbaanvervorming wat individue moet deurleef. Hulle hele spektrum van beroepsverwagtings, wat by sommige oor lojale dienstydperke van twintig en meer jare opgebou is, word ewe skielik heeltemal verander. Hulle verwagtings realiseer (al is dit slegs hulle eie waarnemings) nie meer nie, hulle bou illusies oor werkverlies en beskou bestuur, wat die oorsaak vir die dilemma is waarin die organisasie verkeer, as onregverdig om sulke nuwe eise te stel. Daar is veral baie verwysing na die feit dat bestuur skotvry kom terwyl die 'onskuldige' werker die prys betaal.

Die alleroorheersende rede vir ontevredenheid, aldus die opinie van die skrywers, is die hele kwessie van werksekuriteitsbedreiging. Die vrees word gevoed deur personeelverminderings (dit is amper onafskeidbaar deel van destruktiewe rasionalisasie, hetsy dit nodig of onnodig is), en oordrewe beklemtoning van prestasie terwyl die rolle van personeel nog heeltemal onduidelik is. Die skrywers het in $58 \%$ van die gevalle opgeteken dat werknemers langer as 12 maande gewag het vir hulle bevestiging van hulle heraanstellings en duidelikheid oor hulle nuwe poste. Terwyl hulle gewag het op rolduidelikheid is hulle self vir 'n periode van tot agt maande 'geterroriseer' met 'werk harder of loop' dreigemente. 'n Mens kan nie hard werk as jy bedreig voel nie, nog minder as jy weet jy gaan definitief 'n rolverandering deurleef, nog minder as jy 'n sterk vermoede het jy gaan jou werk verloor en glad nie as jy nie weet wat jou nuwe pos behels nie! In hierdie studie het $68 \%$ van die respondente aangedui dat hulle bedanking baie sterk oorweeg het; die meeste kon dit egter nie ten uitvoer bring nie omdat die swak ekonomie hulle nie kon akkommodeer nie, of omdat hulle 'n lewenslange belegging in diensjare het, of omdat hulle 'n gespesialiseerde beroep volg wat nie buite hul ondernemings maklik beskikbaar is nie.

Dit blyk vir die skrywers asof die vrees vir werkverlies en die stimulasie van gerugte daaroor, baie werknemers tot irrasionele gedagtegange dwing. Hulle lewe in 'n selfgeskepte illusie dat hulle ook hulle werk sal verloor, maar hoop terselfdertyd dit gebeur nie. Hulle is dus rigtingloos omdat hulle nie weet of hulle nuwe werk moet soek nie en of hulle bestuur met hul loopbane moet vertrou nie. 


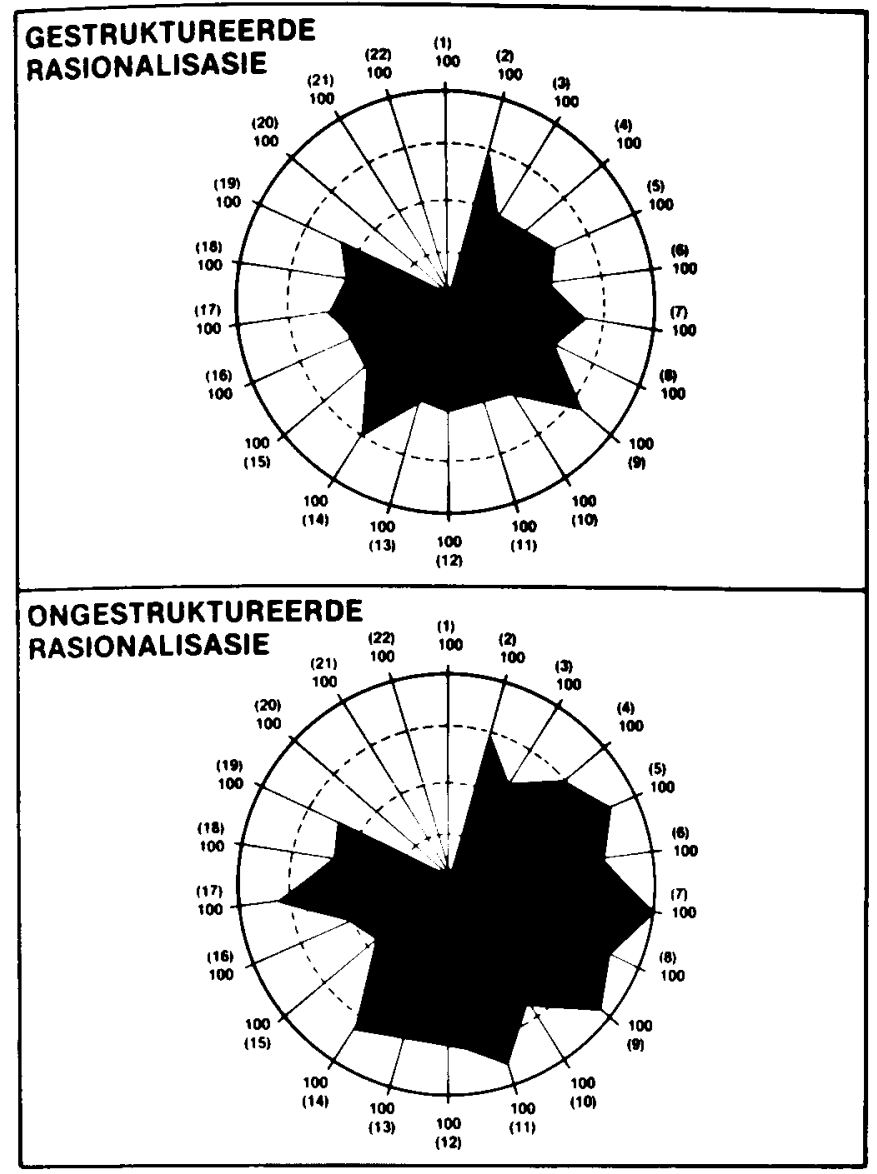

Figuur 2 Radarprofiel: Negatiwiteit ervaar tydens gestruktureerde en ongestruktureerde rasionalisasies

\section{Suksesse van verskillende bestuursbenaderings}

Deur die response van respondente te vergelyk tussen ondernemings waar rasionalisasie in streng gestruktureerde formaat plaasvind teenoor ondernemings waar rasionalisasie op ' $n$ meer losse basis hanteer word en die proses amper tydloos is, het die skrywers bevind dat ontevredenheid tydens albei pogings hoogty vier, maar dat die ontevredenheid by werknemers waar pogings ongestruktureerd is baie meer intens beleef word. Onderstaande radarmodel beeld hierdie bevindinge baie duidelik uit. Dieselfde faktore soos vir die eerste model is ter sprake. Let op die baie duidelike korrelasie tussen die voorkoms van die profiele met die een profiel wat heelwat groter in ruimte is.

\section{Profiel van 'n onteurede rasionalisasiemeelewer}

Vanuit bogenoemde het die skrywers bevind dat die profiel van 'n ontevrede rasionalisasiemeelewer soos volg geskets kan word.

- Sy werksekuriteit word bedreig. Dit gebeur hoofsaaklik weens die lang termyn van afhandeling van die proses, sonder persoonlike inligting beskikbaar en weens die induksering van personeelverminderingsprogramme. Hy is dus onseker van homself en 'n toekomstige werk. Smith (1982: 33) noem hierdie vrees vir verandering waarin werkverlies prominent is 'the great immobiliser'.
- Hy is oningelig of nog erger halfingelig, oor primêr sy eie posisie en ervaar dus kommunikasie as swak. Dit gebeur as gevolg van verskeie faktore soos:

- gebrek aan detailbeplanning rakende mannekrag

- toesighouers wat slegs opwaarts kommunikeer weens eie onsekerheid

- gerugte

Weens sy half ingeligte omstandighede visualiseer hy vir homself ' $n$ uitkoms; weens die bedreiging hierbo is dit hoofsaaklik ' $n$ visie van werkverlies.

- Hy ervaar gebrek aan eienaarskap, omdat hy weens ondernemingsgrootte en sy status, geen inspraak gegun is in die proses nie. Uiteraard het elkeen sy eie vernuwingsgedagtes. Wanneer dit nie klop met wat bestuur infaseer nie en die bedreiging begin hom aantas, reageer hy negatief.

- Hy is belangeloos, laag gemotiveer en ervaar die wanorde van herstrukturering as 'n ingreep op sy vermoë om te produseer. Die lae produktiwiteit word toegedig aan 'n gebrek aan rolduidelikheid, verbrokkeling van groepskohesie, spanning oor 'n nuwe werk, personeelvermindering en vele meer. Sy psigiese energie is gekanaliseer na oorlewing eerder as produksie.

- Hy beleef lae vertroue in bestuur en sy lojaliteit daal omdat sy verwagtings van vroeër verander, nuwe eise gestel word sonder versekering van werk en personeelvermindering homself of sy makkers rondom hom bedreig. Dit word vererger deur gerugverspreiding, swak kommunikasie en die lang termyn van onsekerheid, omdat die proses kompleks is en moeilik implementeer.

- Hy ervaar die beplanning en herstruktureringsproses as swak, suiwer omdat daar nie vir sy detailbelange voorsiening gemaak is nie.

- Sy ego word afgetakel weens die ongelyke infasering van die proses, met ander woorde sy makkers kan vroeër as hy bevestiging kry van aanstellings. Dit laat 'n gevoel van minderwaardigheid.

- Hy kan glo dat hy 'n ondergemiddelde presteerder is en sy kanse op indiensneming as swak ag. Dit is nie noodwendig so nie.

Indien slegs die eerste punt ten opsigte van werksekuriteit geldig is en gefasiliteer word deur swak afwaartse kommunikasie, dan is die skrywers oortuig dat ontevredenheid oor al die ander faktore heen ervaar sal word.

Vanuit die eerste fase van die studie kom die skrywers dan tot die gevolgtrekking dat rasionalisasie, al is dit vir 'n termyn, ' $n$ erodeerder is van lojaliteit, vertroue en perspektief in die werk en dat hierdie gevoel hoofsaaklik veroorsaak word omdat die werknemer rasionalisasie beleef as 'n poging om sy werkslewe te vernietig. Uiteraard weens die absolute verbintenis van enige mens met sy beroepsloopbaan sal rasionalisasie as 'n terreuraksie op sy lewensreg beleef word. Veral waar personeelvermindering inherent aan die proses is. Laasgenoemde is amper 'n outomatiese voortvloeisel van die vernuwingsaksie. Werknemers ervaar ook veral die negatiwiteit omdat hulle voel bestuur het die 
onderneming na wanorde gelei, maar nou betaal die 'onskuldige' werknemer die prys.

\section{Werksekuriteitsbedreiging}

Bogenoemde waarnemings is primêr afgelei uit oopeindevrae. Ten einde die skrywers se moontlike subjektiwiteit om 'n werklike korrekte afleiding te maak, uit te skakel, is 'n verdere vraelys ontwikkel wat werksekuriteit spesifiek tydens rasionalisasie meet. Die vraelys is vanuit drie fronte benader:

1. Herzberg se kritiese insidentmetode is gebruik om te bepaal watter faktor in die ondernemingsrasionalisasiemeelewer se hiërargie van motiveerders en higiënefaktore die grootste mate van tevredenheid en ontevredenheid veroorsaak het.

2. Watter posisie werksekuriteit beklee in terme van 13 verskillende faktore wat uit die teorie ten opsigte van die mens en sy verbintenis met sy werk geïdentifiseer is.

3. 'n Wye reeks vrae ten opsigte van die individu se behoefte aan werksekuriteit en die mate van bedreiging wat deurleef is. Die toets is weer eens in ondernemings gedoen waar gestruktureerde en ongestruktureerde metodiek gevolg is. 'n Baie interessante resultaat het hieruit voortgevloei.

Ten opsigte van die kritiese insidente is bevind dat al die ondernemings waar steekproewe getrek is aan higiëneskok lei. Dit is 'n toestand waar een of meer higiënefaktore prominent uit plek in die normale profiel is en waar sommige motiveerders ook as faktore voorkom wat die individu tot ontevredenheid stem. 'n Absolute kommerwekkende neiging ten opsigte van ontevredenheid met werksekuriteit kom voor. Soveel as $32 \%$ respondente was ontevrede met werksekuriteit in die gestruktureerde proses (ses maande na afhandeling) en $63 \%$ het dieselfde neiging in die ongestruktureerde proses getoon. Dit is beduidend hoër as die $3-4 \%$ wat normaalweg deur Hertzberg in sy studies gevind is.

Ten einde absolute objektiwiteit te verkry oor die interpretasie van die kritiese insidente, is die antwoorde onafhanklik deur die skrywers geëvalueer. 'n Interbeoordelaarsooreenkoms is daarna uitgewerk volgens die metode van Scott \& Wertheimer (1962: 195196) om te bepaal in watter mate die resultate statisties beduidend dieselfde geklassifiseer is. Die resultaat word in Tabel 1 uiteengesit.

Die interbeoordelaarsooreenkoms ten opsigte van faktor 1 (erkenning) is bv. soos volg bereken:

CLAASSEN

\begin{tabular}{l|c|c|c|c}
\hline & $\begin{array}{r}\text { Ooreen- } \\
\text { stemmend }\end{array}$ & $\begin{array}{r}\text { Nie oor- } \\
\text { eenstemmend }\end{array}$ & \\
\hline B Ooreen- & 11 & 5 & 16 & \\
A stemmend & 6 & 186 & 192 & \\
C Nie ooreen- & & & 208 & \\
E stemmend & 17 & 191 & \\
R
\end{tabular}

$$
\left.\begin{array}{rl}
\operatorname{Pe} & =\left\{\frac{(17+16) / 208}{2}\right\}^{2}+\left\{\frac{(191+192) / 208\}^{2}}{2}\right\} \\
& =\{0,00062
\end{array}\right\}
$$$$
\mathrm{Po}=11+186
$$

\begin{tabular}{|c|c|c|c|c|c|c|c|c|c|c|c|c|c|c|}
\hline $\begin{array}{l}\mathbf{B} \\
\mathbf{A} \\
\mathbf{C} \\
\mathbf{K} \\
\mathbf{E} \\
\mathbf{R}\end{array}$ & 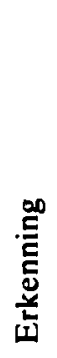 & 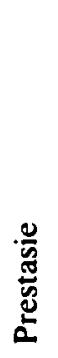 & $\bar{\Xi}$ & $\begin{array}{l}\stackrel{\infty}{0} \\
.0 \\
0 \\
0 \\
0 \\
0 \\
0 \\
0\end{array}$ & $\frac{n}{\frac{\pi}{\pi}}$ & $\begin{array}{l}\frac{\infty}{00} \\
\stackrel{0}{0} \\
\stackrel{0}{6}\end{array}$ & 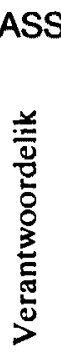 & 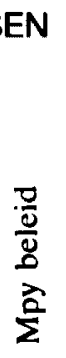 & 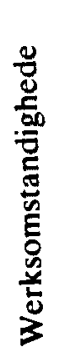 & 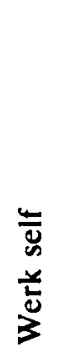 & 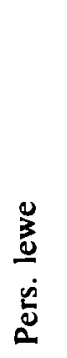 & $\stackrel{n}{\stackrel{n}{*}}$ & 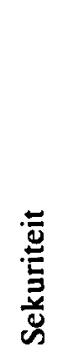 & \\
\hline Erkenning & 11 & 1 & $\mathbf{0}$ & 0 & 1 & 0 & 0 & 0 & $\mathbf{0}$ & 1 & 0 & 0 & 2 & 16 \\
\hline Prestasie & 1 & 19 & 0 & 0 & $\mathbf{0}$ & 0 & $\mathbf{0}$ & 0 & $\mathbf{0}$ & 0 & 0 & 0 & 0 & 20 \\
\hline Groei & 0 & $\mathbf{0}$ & 4 & 0 & 0 & 0 & 0 & 0 & $\mathbf{0}$ & $\mathbf{0}$ & $\mathbf{0}$ & $\mathbf{0}$ & 0 & 6 \\
\hline Bevordering & 1 & 0 & 0 & 3 & $\mathbf{0}$ & $\mathbf{0}$ & 0 & $\mathbf{0}$ & $\mathbf{0}$ & 0 & 0 & $\mathbf{0}$ & 0 & 4 \\
\hline Salaris & 0 & $\mathbf{0}$ & 0 & 0 & 3 & 0 & 0 & 0 & 0 & $\mathbf{0}$ & 0 & $\mathbf{0}$ & 0 & 3 \\
\hline Toesig & 1 & $\mathbf{0}$ & 0 & $\mathbf{0}$ & 0 & 35 & $\mathbf{0}$ & 2 & $\mathbf{0}$ & 0 & $\mathbf{0}$ & $\mathbf{0}$ & 1 & 39 \\
\hline Verantwoordelik & $\mathbf{0}$ & $\mathbf{0}$ & 0 & $\mathbf{0}$ & 0 & 1 & 5 & 1 & 0 & 0 & 0 & 0 & 2 & 9 \\
\hline Mpy beleid & $\mathbf{0}$ & 2 & $\mathbf{0}$ & 2 & 0 & 1 & 0 & 22 & 0 & $\mathbf{0}$ & 1 & $\mathbf{0}$ & $\mathbf{0}$ & 28 \\
\hline Werksomstandighede & 1 & $\mathbf{0}$ & 2 & 1 & $\mathbf{0}$ & $\mathbf{0}$ & 0 & $\mathbf{0}$ & 1 & 1 & 0 & 0 & 2 & 9 \\
\hline Werk self & 2 & $\mathbf{0}$ & 3 & $\mathbf{0}$ & 0 & 4 & 3 & $\mathbf{0}$ & 3 & 8 & 2 & 0 & $\mathbf{0}$ & 25 \\
\hline Pers. lewe & $\mathbf{0}$ & 0 & $\mathbf{0}$ & 0 & 0 & $\mathbf{0}$ & 0 & $\mathbf{0}$ & 0 & $\mathbf{0}$ & $\mathbf{0}$ & 0 & $\mathbf{0}$ & 0 \\
\hline Status & $\mathbf{0}$ & 0 & $\mathbf{0}$ & 0 & $\mathbf{0}$ & 0 & $\mathbf{0}$ & 0 & 0 & 0 & $\mathbf{0}$ & 0 & 0 & $\mathbf{0}$ \\
\hline \multirow[t]{2}{*}{ Sekuriteit } & $\mathbf{0}$ & 1 & 0 & $\mathbf{0}$ & $\mathbf{0}$ & 0 & $\mathbf{0}$ & 0 & $\mathbf{0}$ & 0 & $\mathbf{0}$ & 1 & 48 & 49 \\
\hline & 17 & 22 & 11 & 6 & 3 & 41 & 8 & 25 & 4 & 10 & 3 & 2 & 55 & 208 \\
\hline
\end{tabular}

Tabel 1 Kodifiseringsmatriks ten opsigte van 13 Hertzbergfaktore. Tevredenheidsen ontevredenheidsresponse gekombineer 
Tabel 2 Indeks van ooreenkoms tussen beoordelaars

\begin{tabular}{lc}
\hline Faktor & \\
Erkenning & 0,64 \\
Prestasie & 0,89 \\
Groei & 0,69 \\
Bevordering & 0,60 \\
Salaris & 1,0 \\
Toesig & 0,86 \\
Verantwoordelikheid & 0,60 \\
Maatskappybeleid & 0.80 \\
Werksomstandighede & 0,40 \\
Werk self & 0,40 \\
Persoonlike lewe & Nie bereken \\
Status & Nie bererken \\
Sekuriteit & 0,87 \\
\hline
\end{tabular}

$$
\begin{aligned}
\text { Po }= & \frac{11+186}{208} \\
= & 0,947 \\
& \frac{P o-P e}{1-P e} \\
= & \frac{947-853}{1-853} \\
= & 0,639
\end{aligned}
$$

Scott \& Wertheimer (1962: 195-196)

Die indeks van ooreenkoms (Tabel 2) het hieruit voortgevloei.

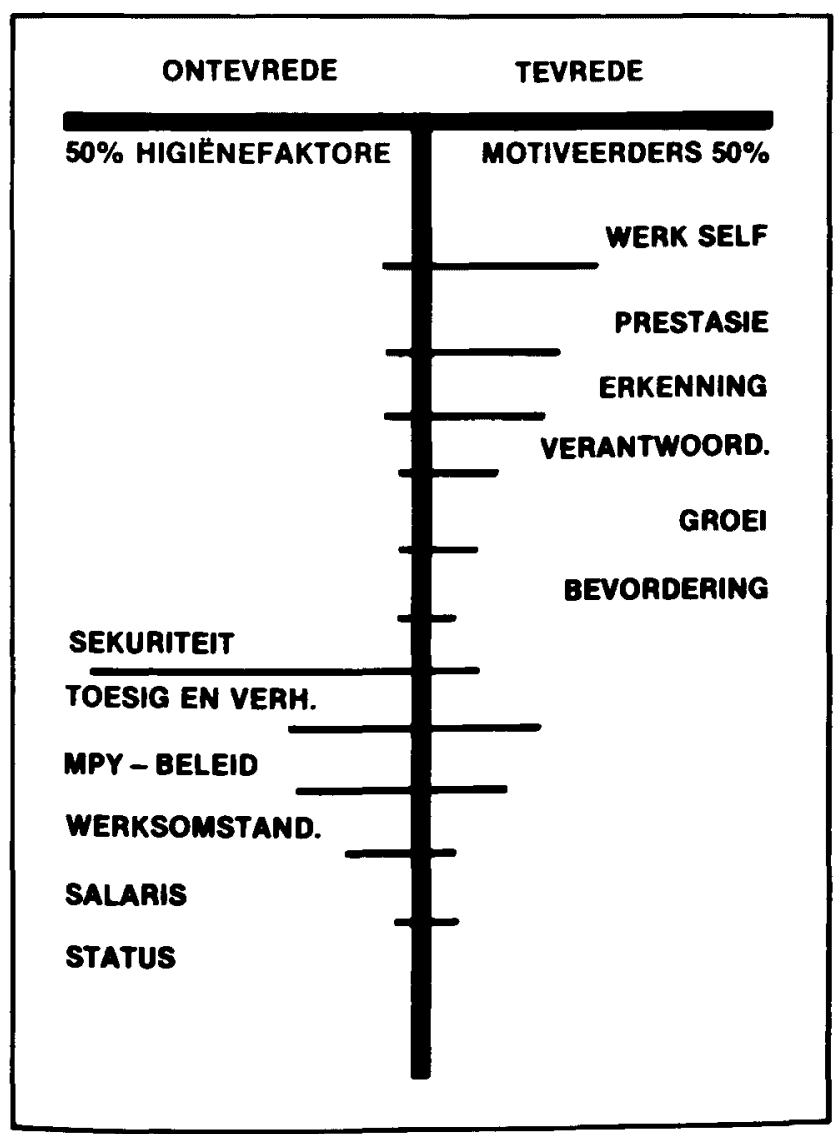

Figur 3 Hertzbergprofiel ten opsigte van kritiese insidente
Die boonste grens van hierdie indeks $=1$. 'n Indeks van 0 impliseer geen ooreenkoms tussen die beoordelaars nie met ander woorde die resultaat kan aan kans toegeskryf word. Die mate van ooreenkoms kan as bevredigend beskou word omdat agt uit die elf berekende faktore hoër of gelyk aan 0,6 is.

Beduidende interpretasieverskille is slegs tussen twee faktore naamlik werk self en werksomstandighede verkry.

Die resultaat vir die totale populasie is skematies in Figuur 3 voorgestel.

Wat die faktorrangorde betref, het werksekuriteit in albei gevalle die hoogste prominensie verkry. Veertig persent van die respondente het werksekuriteit eerste geplaas in hul rangorde. Die faktor wat die tweede beste gevaar het was verantwoordelikheid met $15 \%$. 'n Verdere $25 \%$ respondente het werksekuriteit as tweede en derde belangrikste in hul behoeftehiërargie geplaas. Werksekuriteit, aldus die opinies van die skrywers, het tydens rasionalisasie ' $n$ baie hoë aansien en na mening word dit veroorsaak deur die hoë mate van werkverliesvrees wat oor die tydperk van rasionalisasie op hulle afgeforseer word. Die verskynsel is soveel meer betekenisvol omdat die meting ten opsigte van werksekuriteit geneem is ses maande nadat die gestruktureerde rasionalisasies afgehandel was. Die ongestruktureerde prosesse was steeds aan die gang.

Ten opsigte van die sekuriteitsbehoefte van sekuriteitsbedreiging spesifiek, is sowat 32 vrae aan werknemers gevra. Die werknemer moes 'n punt op 'n vierpuntskaal ten opsigte van sy gevoel oor die saak toeken op elke vraag. Die antwoorde is by wyse van die Hotelling $T^{2}$-toets verwerk soos beskryf in Morrison (1976: 128-141). Die tegniek vergelyk 'n vektor van gemiddeldes met ' $n$ vektor van gemiddeldes oor 'n hele groepering vrae, tussen verskillende populasies. 'n $P$ waarde van 0,05 of kleiner toon 'n beduidende verskil in ervarings tussen populasies. Die toets het baie duidelik getoon dat die behoefte na sekuriteit baie groot is, maar dat die populasies waar die steekproef getrek is geen verskil in sekuriteitsbehoefte openbaar nie. ' $n P$-waarde van 0,56 het gerealiseer. Wat die sekuriteitsbedreiging betref, is ' $n$ uiters beduidende verskil bevestig met 'n $P$ waarde van 0,00001 . Die bevinding is dat werknemers in ongestruktureerde situaties statisties gesproke sowat 10 000 keer meer bedreig voel as werkers waar meer gestruktureerde pogings met spesifieke tydsgrense geloods word.

Die bevindinge word skematies in radarformaat voorgestel in Figuur 4. Die profiele is getrek suiwer vanaf die kumulatiewe frekwensies ten opsigte van punte wat respondente aan vrae toegeken het. Let op die duidelike verskil in bedreiging en die duidelike ooreenkoms in behoefte. Dit versterk die statistiese bevindinge.

Die volledige statistiese resultaat vir die Hotelling $T^{2}$ toets is in Tabel 3 uiteengesit.

Tabel 4 is ' $n$ tipiese statistiese resultaat ten opsigte van 'n enkele vraag bv. 'Dink $u$ dat werksekuriteit vir $u$ as individu ' $n$ voorvereiste is, voordat $u$ in staat is tot optimale produktiwiteit?' 


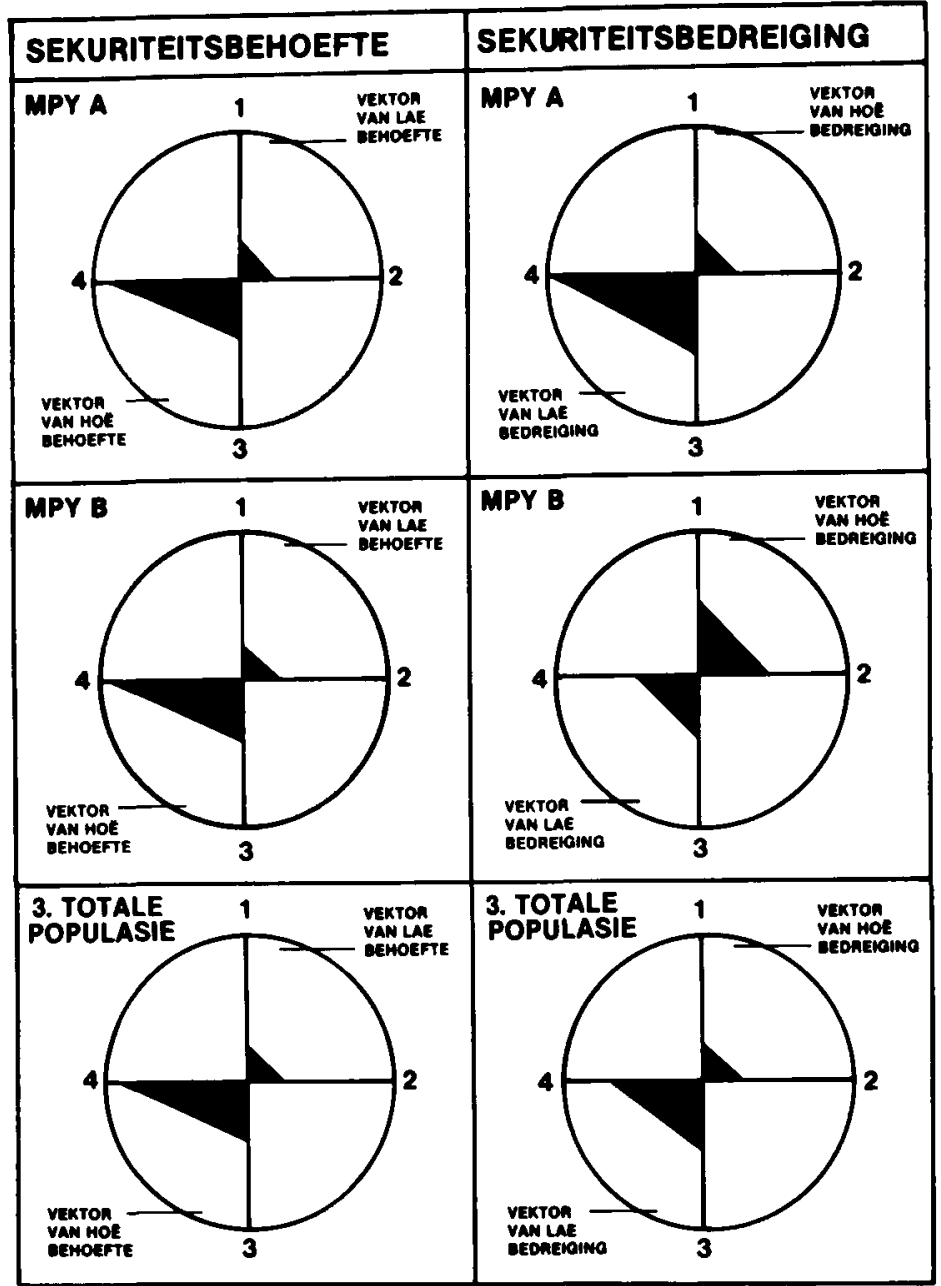

Figuur 4 Radarprofiel: Hotelling $T^{2}$-resultate

Tabel 3 Hotelling $T^{2}$ toetsresultaat t.o.v. sekuriteitsbedreiging en -behoefte

\begin{tabular}{llll}
\hline \multicolumn{2}{c}{ Sekuriteitsbehoefte } & \multicolumn{2}{c}{ Sekuriteitsbedreiging } \\
\hline Mahalanobis $D^{2}$ & $=0,2521$ & Mahalanobis $D^{2}$ & $=4,7050$ \\
Hotelling $T^{2}$ & $=6,0839$ & Hotelling $T^{2}$ & $=113,5578$ \\
F-waarde & $=0,8313$ & $F$-waarde & $=5,5316$ \\
Grade van vryheid & $=7,183$ & Grade van vryheid & $=18,121$ \\
$P$-waarde & $=0,5631$ & $P$-waarde & $=0,00001$ \\
\hline
\end{tabular}

L.W. 'n $P$-waarde van kleiner of gelyk aan 0,05 dui 'n beduidende verskil aan tussen die populasies waar die steekproef getrek is

Al die antwoorde uit enkelvrae is in vektore gegroepeer en hierdie vektore is met mekaar vergelyk tussen maatskappye om te sien of die verskillende populasies verskillende toekennings gemaak het. Die populasies is ewekansig saamgestel en word as verteenwoordigend beskou.

Bo en behalwe die bevindinge ten opsigte van die behoefte aan sekuriteit en die bedreiging wat ervaar word kon die skrywers ook duidelik vasstel dat werknemers nie soseer verandering vrees nie, maar eerder die werksekuriteitsbedreigingskomponent daarvan. 'n Baie sterk vermoede bestaan dan ook dat
Tabel 4 Statistiese toetsresultaat ten opsigte van 'n enkele vraag

\begin{tabular}{lcccc}
\hline & $P$-waarde & & Mpy A & Mpy B \\
\hline$T$ (onafhanklik) & 0,1118 & Mediaan & 3,0183 & 3,3226 \\
$T$ (gegroepeer) & 0,1577 & Std afwyk & 1,0970 & 0,8713 \\
$F$ (vir variansies) & & SFM & 0,1051 & 0,1565 \\
Levene 1,75 en 0,1877 & & N & 109 & 31 \\
& & Maks & 4 & 4 \\
& & Min & 1 & 1 \\
\hline
\end{tabular}

indien werksekuriteit bevestig kan word, verandering gemakliker en meer geredelik aanvaar word. Steun vir die onderneming se rasioneel vir verandering volg dan bykans outomaties. Negentig persent van die respondente het ook aangedui dat hulle harder werk tydens fases van sekuriteitsekerheid as onsekerheid. Daar bestaan aldus die opinie van die skrywers nie 'n begrip soos 'healthy insecurity' nie en bestuurders wat werksekuriteit aftakel in die hoop dat mense harder sal werk fouteer na mening van die skrywers.

\section{Aanbevelings uit die studie}

Die skrywers wil hulle in die artikel slegs beperk tot aanbevelings ten opsigte van die rol van die 
mannekragbestuurder tydens en na rasionalisasie. Die aanbevelings volg op die bevindinge ten opsigte van werknemers se ervarings en behoeftes asook die aktualiteit en omvang van die rasionalisasieproses wat mannekragbestuur betref.

\section{Aanbevelings t.o.v. die rol van mannekragbestuur- ders tydens rasionalisasie}

Dit is 'n kritieke rol; die belangrikste van almal en een wat selfs bokant die rol van die bedryfsekonomiese eise van en vir rasionalisasie uittroon. Torrington et al. (1985: 10) sê dat 'personnel specialists often feel that it is difficult to demonstrate their departments vital contribution to the enterprises efficiency and success. In this, they are constantly trying to increase the power and authority of the personnel department within the organisation.' Die skrywers sê, dit is 'n vereiste dat dit tydens rasionalisasie gebeur. Dit is essensieel. Die skrywers beveel aan dat mannekragpraktisyns die volgende aspekte deeglik onder die knie kry ten einde hulle rolle te kan volstaan wanneer rasionalisasie realiteit word:

1. Mannekragbestuurders moet kennis dra van en weet op watter fronte rasionalisasie hulle beroep gaan raak. Daar is bykans nie een aktiwiteit van mannekragbestuur wat nie aangeraak word nie. Dit gaan nie altyd oor dinge reg doen nie, maar ook om die regte ding te doen ... daar moet visie gegenereer word oor watter eise gestel gaan word ... 'it will become the link between dream and action' (Naisbut, 1985: 40) $\ldots$ en onthou al die aktiwiteite vra gelyktydig aandag.

2. Besef die werklike gevoel wat u werknemers gaan beleef. Dit is die rol van die Mannekragbestuurder om besluite van uitvoerende bestuur so te rig dat dit die minimum hoeveelheid werksekuriteitbedreiging en gepaardgaande produktiwiteitsverlies veroorsaak. Dit kan alleenlik geskied as rasionalisasie se invloed op die gewone werksmens by uitnemendheid verstaan en besef word. Smith (1982: 33) sê dat 'the major challenge became finding ways to refocus the energy of the remaining staff towards achievement of the organisation's goals and objectives.' Die skrywers steun dit ten volle.

3. Kry die onderneming se mannekragbeleid sodanig in orde dat

- personeelvermindering deeglik omskrywe, onderhandel en gevestig is;

- vergoedingsbestuur so omskryf is dat dit ook die sogenaamde personeelverminderingsloon omskryf;

- herontplooiings, verplasings en skommelinge vinnig en akkuraat hanteer kan word;

- arbeidsreg deeglik deurtrap is; en

- 'n rasionalisasieprosedure moet met vakunies beding word.

4. Mannekragpraktisyns moet die implikasies van alle rasionaliseringstegnieke op die organisasie verstaan. Dit kan verhoed dat tegnieke gekies word wat oor'n paar jaar weer teen die organisasie gaan boemerang.

5. Hou die verbintenis met vakunies op 'n oop en werklike vertrouensbasis. Indien teenkanting in die stryd van rasionalisasie vanaf die front sodanig word dat die proses vertraag word, word die trauma vir werknemer en organisasie ' $n$ onsmaaklike belewenis. 6. Rasionalisasie moet spoedig, effektief en feitlik eenmalig wees. Ongestruktureerde intervensies wat amper tydloos raak is oneindig skadelik vir die onderneming. Mannekragpraktisyns moet hulle hoofbestuur langs hierdie weg kan opvoed en lei.

7. 'n Nougesette evaluasie van die onderneming se arbeidsomset moet gedoen word en die retensie van die onderneming se top personeel moet aktief bestuur word. Onthou dat rasionalisasie nie so eenvoudig is as om net die vet uit te sny nie. Dit errodeer die organisasie se moreel en forseer ampter ' $n$ irrasionele bedankingspatroon.

8. Die aanbeveling wat die skrywers as die belangrikste $\mathrm{ag}$, is dat Mannekragbestuurders nie moet toelaat dat hulle organisasies se mannekragkomplement buite verhouding groot word in bloeitydperke nie. Mannekragbeplanning waar elke pos oor die langtermyn geregverdig word is ' $n$ absolute voorvereiste. Mannekragbestuurders kan nie toelaat dat werknemers slagoffers van misleidende omstandighede word nie. As daar slegs werk vir 'n bepaalde termyn is, moet die werker vir slegs so 'n termyn gekontrakteer word; as die onderneming hom 'n beroepslewe aanbied moet dit op die basis wees dat met alle berekende risiko's in ag geneem, dit 'n vollengte beroepslewe moet word.

9. Personeelpraktis " noet die gedagte by vakunies laat ontkiem dat daat wi. : der oor lone en meer oor werksekuriteit gepraat moet word. Miskien kan daar dan van 'n sterk front oor 'n loonstruktuur onderhandel word wat die organisasie in staat stel om werk te skep en dit te waarborg. Met die minimum vlak van lone wat al hoër deur wetgewing vasgepen word en vakunies se vernietigende loonstrategieë raak werkskepping vir Suid-Afrikaanse bedrywe 'n groter en groter kopseer.

10. Moenie toelaat dat $u$ bruikbare stelsels verander word ter wille van verandering om die rasionalisasiekoors tevrede te stel nie. Rasionalisasie kan oorbelaai en oorgekompliseerd raak deur te vael te gou te probeer regmaak. Mannekragbestulirders moet daarteen waak.

11. Doen kreatiewe opvolgbeplanning. Rasionalisasietegnieke soos desentralisasie en sekere herstruktureringstegnieke waar topstrukture vergroot vereis baie bestuurpotensiaal. Indien hulle nie beskikbaar is nie, gaan die organisasie sy program nie effektief deurvoer nie. Swan (1874: 4) sê dat 'the objective of succession planning is to ensure that suitably qualified and experienced people will be available to fill vacancies as they arise as a result of reorientation!'

12. Kommunikeer eenvoudig en effektief met $u$ werknemers. Kiechell (1986: 86) sê dat 'you have to share lots of information with employees if you hope to elicit their commitment ... commitment means high productivity, low turnover and a better change of avoiding corporate death.' 
13. Kies die tyd vir beklemtoning van prestasie en die tegniek hoe $u$ dit gaan bevorder met 'n baie oop gemoed. Oordrewe prestasiedruk, as angsvlakke hoog is, verlaag eerder produktiwiteit weens hoë negatiewe stres.

Schneier et al. (1986: 38) sê dat die transisie van 'performance appraisal to performance management needs committed managers.' Indien daardie 'commitment' afgebreek word, kan die saak nie suksesvol geïplementeer word nie.

14. Moenie personeel in massa afdank indien dit nie vir u onderneming absoluut noodsaaklik is nie. Wat SuidAfrika en werknemers nodig het, is werkskepping; nie vermindering in poste nie.

\section{Opsomming}

Ondernemingsrasionalisasie met sy vernuwingsdimensie as einddoel word so deur bestuur geprojekteer dat die skewe hoeke van die organisasie reggeskaaf word, al val sommige werkers as saagsels op die grond. Mannekragbestuurders moet die realiteit van rasionalisasie erken en pro-aktief daaraan werk om die trauma vir die onderneming se werker te minimiseer. Rasionalisasie kan uiteindelik weens swak hantering van die werkerskorps so swak ontvang word dat die onderneming se bestuur wanhopig sal probeer om hul pogings deur te voer. $U$ kan nie vernuwing verkoop aan mense wie se beroepslewe bedreig word nie.

Bowe alles moet $u$ besef dat rasionalisasie ' $n$ komplekse, senutergende taak vir die mannekragbestuur word ... die kontraste wat hy op dieselfde oomblik moet bestuur wissel van groei in getalle tot afdanking; van hoë arbeidsomset tot lae vermoë om aan te stel weens beeldskade en beperkings; van hoë kostedruk en streng besnoeiing tot meer geld vir beter prestasie; van positiewe verwagting tot motiveringsverval; van konflik tot prestasie; van bestaan tot oorlewing en van redelikheid tot obsessionele irrasionaliteit. $U$ moet uself slaggereed maak vir die taak!

\section{Summary}

The rationalization of companies in the western world has become almost an integrated part of modern management strategies. The downsizing syndrome has proven to be the favourite choice of many. This study analyses the experiences of employees during the phases of major change. The hypothesis the study tested was that significantly more employees will rate the experience as extremely negative and that the main issue at stake is job security.

Rationalization is the process that an organization would follow to strive towards restructuring its resources or processes in such a way that its ability to survive is guaranteed or its profits are optimized, at least over the medium term. It is an intervention of change which has renewal or survival as its goal. Rationalization can be partial or a total process. During the phases of major rationalization it is typical that management would suffer from a 'rationalization fever'; an inherent need to change not only those processes that need to be changed but also those that need no change. Rationalization in its total format addresses all the business processes at the same time making it an extremely complex process.

It was found that although a significant proportion of employees thought that drastic change was needed in their organizations, they were bitterly unhappy with the way in which management introduced the change. It was also found that at the centre of the unhappiness, threats to job security caused the most damage. Furthermore, it was proven that during rationalization a well-planned, pre-programmed exercise, with a definite beginning and end time, creates significantly lesser stress and fear amongst employees than during an unstructured, almost open-ended process.

What is of significance is that the symptoms of a need for rationalization are experienced by employees long before the process actually takes place. Probably their feelings are part and parcel of the climate inherent in the organization at that moment in time. Employees have their own interpretation of the causes for the symptoms. They are normally in conflict with management's views. A clean picture of workers' perspectives and managements' perspectives develops even long before the change process starts.

Employees normally dissassociate themselves from the process because they have the feeling that their interests were not taken to heart by management. they therefore experience very little ownership.

The primary communication needs of employees during rationalization centre around their own needs re job security, promotion, etc. and the outcome of the organization after change is of secondary importance to them. Rumour mongering normally overrides all the formal communication channels, primarily due to the tremendous amount of insecurity that prevails at that time. It is proposed by Hayes \& Nutman (1981) that as much as $75 \%$ of the individual's psycic energy is projected at survival rather than production. Productivity therefore takes a serious dip during phases of major change.

The majority of workers feel that their loyalty towards an organization is seriously affected by the change process. It is the authors' opinion that this is due to the major proportion of job distortion and insecurity injected into the organization due to the change process.

It was statisticallly proven that about $70 \%$ of any population would associate themselves with those who would be retrenched during the rationalization exercise if only the fact that retrenchment was going to take place was known but the numbers or the individuals were unknown.

The profile of an unhappy rationalization participator would be one where

- his job security is threatened. It happens primarily due to the long time it takes to complete a rationalization program and due to retrenchment that runs parallel with the constructive change processus;

- he is uninformed or half informed and therefore builds his own illusion around the outcome of his standing after rationalization. It is normally a vision of being retrenched; 
- he experiences a lack of ownership of the process because no detail attention was given to his own outcome;

- he lacks interest, is low motivated and experiences the 'chaos' of restructuring as a career-limiting move;

- he experiences low trust in management;

- his ego is attacked and a feeling of inferiority develops.

Rationalization is a very complex and involved process placing specifically high demands on manpower management and employees alike. Organizations who do not plan their rationalization processes very carefully could find themselves in a situation where change becomes cancerous, killing the intervention and the organization in the end.

\section{Verwysings}

Hayes, J. \& Nutman, P. 1981. Understanding the Unemployed. Transdek Publications, London.
Kiechell, W. 1986. No word from an high. Fortune.

Morrison, D.F. 1976. Multivariate Statistical Methods. McGraw Hill, New York.

Malik, H.J. \& Mullen, K. 1975. Applied statistics for Business and Economics. Addeson Wesley, California.

Naisbut, J. 1985. Future Visions in Personnel Management" Ongepubliseerde Artikel. New York.

Schneier, C.E., Bealty, R.W. \& Baird, C.S. 1988. How to construct a successful Reformance Appraisal System. Train. Develop. J.

Scott, W.A. \& Wertheimer, M. 1962. Introduction to Psycological Reserach.John Wiley Publ. New York.

Smith, M.E. 1982. Shrinking Organisations: A Management Strategy for downsizing. Bus. Quart., Winter.

Swan, S.R. 1974. Management succession Development. Manage. Action.

Torrington, D., McCay, D. \& Hall, L. 1985. The changing Nature of Personnel Management. E R., vol.7, No 5. 